\title{
UNSCHEDULED DNA SYNTHESIS AFTER PARTIAL UV IRRADIATION OF THE CELL NUCLEUS
}

\author{
Distribution in Interphase and Metaphase
}

\author{
CHRISTIAN ZORN,' CHRISTOPH CREMER,' THOMAS CREMER ${ }^{2}$ and JÜRGEN ZIMMER' \\ Institute of Human Genetics, University Freiburg i.Br, D-7800 Freiburg, and \\ ${ }^{2}$ Institute of Anthropology and Human Genetics, University Heidelberg, D-6900 Heidelberg, W. Germany
}

\begin{abstract}
SUMMARY
Cells of an euploid strain of the Chinese hamster synchronized in the G1 phase were microirradiated in the nucleus with a laser UV microbeam $(\lambda=257 \mathrm{~nm})$ and pulse-labelled with $\left[{ }^{3} \mathrm{H}\right]$ thymidine. In autoradiographs of cells fixed immediately after the pulse unscheduled DNA synthesis (UDS) was found restricted to the microirradiated part of the nucleus. The rate of UDS varied with the UV energy applied and the post-irradiation incubation time. In other experiments chromosome preparations were established after an additional chase and a subsequent growth period. In 28 mitotic cells autoradiographic label was found concentrated on a few chromosomes which lay adjacent to each other in one part of the metaphase plate. The distribution of label on the chromosomes could clearly be distinguished from patterns which originate from semi-conservative DNA synthesis within $S$ phase. The label on chromosomes of microirradiated cells thus represents UDS. Our findings support the following ideas on the arrangement of interphase chromosomes: (1) Decondensed interphase chromosomes may occupy rather compact territories. (2) Chromosomes do not necessarily exhibit a close and permanent association with their respective homologues.
\end{abstract}

Incorporation of $\left[{ }^{3} \mathrm{H}\right]$ thymidine into non-S phase cells (unscheduled DNA synthesis, UDS [1]) has been observed in cells of different origin after treatment with DNA damaging agents [2]. UDS observed after UV microirradiation of tissue culture cells [3-9] has recently been introduced as a tool to investigate the correlation of the chromosome arrangement in metaphase and in interphase. Sakharov et al. [8,9] performed UV microirradiation of anaphase chromosomes and used UDS to relocate the irradiated chromatin in the nuclei of daughter cells. An investigation of the arrangement of interphase chromosomes using this approach is, however, limited for two reasons: (a) In general chromosomes can be only very poorly identified within a living mitotic cell; and $(b)$ the arrangement established after irradiation might be abnormal due to UV-induced alterations (e.g. stickiness) of the irradiated chromatin [7]. These limitations do not apply to an approach in which the cell is irradiated during interphase and the irradiated chromatin is identified in chromosome preparations made in the following metaphase. In this case the cell is allowed to establish the interphase arrangement of chromosomes prior to irradiation. The identification of the irradiated chromatin in the next metaphase would allow to investigate this arrangement. This analysis 

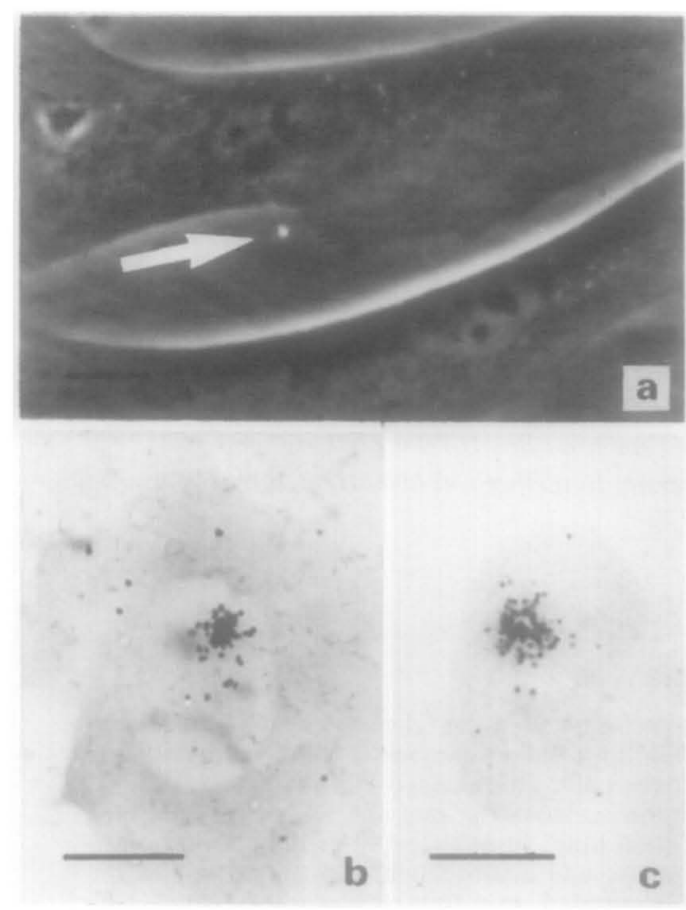

Fig. 1. (a) Phase contrast micrograph showing two Chinese hamster cells and a fluorescent spot (arrow) induced in the substratum by the laser UV microbeam; $(b, c)$ autoradiographs of cells after UV microirradiation and incubation with $\left[{ }^{3} \mathrm{H}\right]$ thymidine for $2 \mathrm{~h}$; (b) fixation after the label period; (c) fixation $48 \mathrm{~h}$ after UV microirradiation after an additional incubation period and hypotonic treatment (schedule B). Bar, $10 \mu \mathrm{m}$.

can be performed even if the arrangement of chromosomes should be grossly disturbed by effects of irradiation and postirradiation procedures. Experiments using chromosome damage as a "label" for irradiated chromatin have been reported [10]. In the present investigation UDS was used as a label which was induced by laser UV microirradiation of a small part of the interphase nucleus. Data are presented on the spatial distribution of UDS within microirradiated nuclei as well as findings of UDS on chromosomes of the subsequent metaphase.

\section{MATERIAL AND METHODS}

\section{Laser microbeam}

The laser UV microbeam has been described in detail elsewhere $[11,12]$. Briefly, a continuous wave coherent UV beam of wavelength $257 \mathrm{~nm}$ is focused to one site in a cell with a quartz microscope objective (Zeiss Ultrafluar $32 \times / 0.40 \mathrm{Ph}$ Glyz.) which is simultaneously used for observation of the cells in phase contrast. The smallest beam diameter in the cells as estimated from fluorescence $[11,13]$ was $1-2 \mu \mathrm{m}$ (fig. 1a). The UV power incident at the cell surface was approx. $7.5 \times 10^{-9} \mathrm{~W}$, the irradiation time was $70 \mathrm{~ms}$.

\section{Cell cultures and conditions of microirradiation}

Cultures of a diploid fibroblastoid strain of the Chinese hamster with a doubling time of approx. $24 \mathrm{~h}$ were established and grown as previously described [10]. Cells of passage number 12-14 were used for the experiments. $Q$ banding analysis revealed a normal female karyotype. The ability of this cell strain to perform UDS has been shown in whole cell UV irradiation experiments [14].

For microirradiation experiments mitotic cells were shaken off from growing cultures and seeded into the center of $6 \mathrm{~cm}$ plastic Petri dishes (Nunc/Denmark). At this site 36 experimental fields of approx. $0.25 \mathrm{~mm}^{2}$ each were marked by scalpel cuts in a $3 \mathrm{~mm}$ square. The cells were incubated in medium with $0.5 \%$ fetal calf serum (FCS) to keep them within the Gl phase of the cell cycle. Direct preparations of mitotic populations showed that $90-98 \%$ of the cells were in mitosis. After the incubation period of $20 \mathrm{~h}$ between 2 and $20 \%$ of the cells were found to be in $\mathrm{S}$ phase. The variation might be caused by a differing response of the cells to the serum deprivation. Twenty hours after seeding cells which lay within experimental fields and which showed a clearly distinguishable nuclear outline were selected for microirradiation at one randomly chosen site of the karyoplasm $[10,12,13]$. After irradiation the cells were incubated for $2 \mathrm{~h}$ with medium without FCS containing $10 \mu \mathrm{Ci} / \mathrm{ml}\left[{ }^{3} \mathrm{H}\right]$ thymidine (Amersham, spec. act. $47 \mathrm{Ci} / \mathrm{mmol}$ ) and $3 \mu \mathrm{g} / \mathrm{ml}$ ethidium bromide (EB). EB was used to reduce cytoplasmic labelling [15]. If not stated otherwise the $\left[{ }^{3} \mathrm{H}\right]$ thymidine pulse was applied immediately after irradiation. After the label period the cells were further processed either according to schedule A or to schedule B.

Schedule $A$. The cells were washed 4 times with Hank's solution, fixed for $10 \mathrm{~min}$ in $3 \%$ glutaraldehyde, and washed with Sörensen buffer $[4,5,15]$. Five changes of ice-cold $2 \%$ perchloric acid (PCA) including one incubation overnight were used to remove non-incorporated $\left[{ }^{3} \mathrm{H}\right]$ thymidine.

$S c h e d u l e B$. After the label period followed a chase period, 4 incubations of $1 \mathrm{~h}$ duration each, with medium containing $10^{-5} \mathrm{M}$ "cold" thymidine and $0.5 \%$ FCS, the first of these with the further addition of EB. Thereafter the cells were allowed to proceed through the cell cycle by feeding with fresh medium with $15 \%$ FCS. Fortyfive hours after irradiation colchicine (1 $\mu \mathrm{g} / \mathrm{ml}$ ) was added for $3 \mathrm{~h}$ and chromosome prepara- 


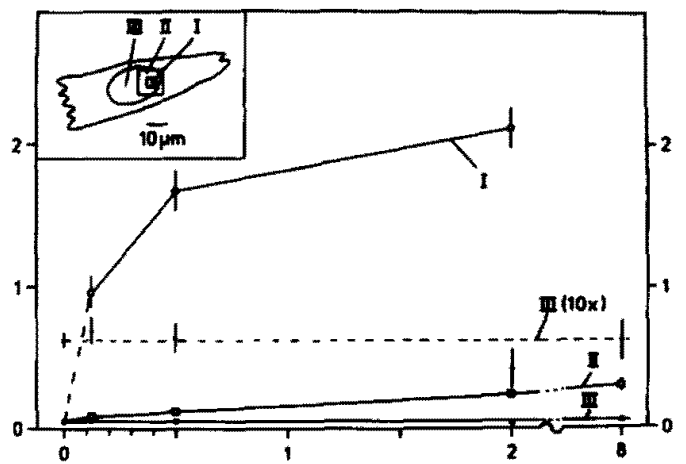

Fig. 2. Abscissa: incident UV energy/cell (nJ); ordinate: UDS (grains/ $/ \mathrm{mm}^{2}$ ).

Unscheduled DNA synthesis in different nuclear regions of cells microirradiated in the nucleus and treated following schedule A. Using an ocular grid with $4 \mu \mathrm{m}$ squares the nuclear area was divided into three parts. (Inset): I, Irradiation site (O); II, nuclear area adjacent to the irradiation site (D); III, nuclear area remote from the irradiation site (C). Plot III is also shown in an extended scale (-..). The error bars indicate S.D.M., the numbers of evaluated nuclei are 59 (no irradiation), $20(0.13 \mathrm{~nJ}), 15(0.5 \mathrm{~nJ}), 17$ $(2 \mathrm{~nJ})$, and $11(8 \mathrm{~nJ})$. Nuclei were evaluated from experimental and control fields within the same Petri dish. The data are typical for several similar experiments $[4,15]$.

tions $[10,15]$ were made. During preparation the cells remained in situ attached to the substratum. The incubation time chosen takes into account the UVinduced mitotic delay.

Sham-irradiated cells in control dishes as well as cells growing outside the experimental fields served as controls.

Unstained cell preparations were scored and metaphase plates were photographed in phase contrast.

\section{Autoradiography}

Cells contained in intact Petri dishes were covered with Ilford nuclear emulsion $\mathrm{K} 2$ and processed following standard procedures [15]. Exposure time at $4^{\circ} \mathrm{C}$ was two weeks. Autoradiographs were stained with acetic orceine and metaphase plates were relocated and photographed.

\section{RESULTS}

\section{UDS observed during the first hours after microirradiation}

Cells were microirradiated at one site in the nucleus and fixed immediately after the label period. In the majority of non $S$ phase

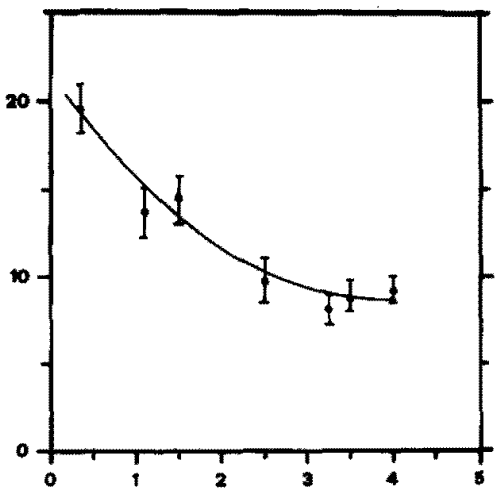

Fig. 3. Abscissa: start of the $\left[{ }^{3} \mathrm{H}\right]$ thymidine pulse (hours after irradiation); ordinate: grain no./nucleus at the irradiation site.

Cells were microirradiated at one nuclear site and incubated in the presence of "cold" thymidine $\left(10^{-7} \mathrm{M}\right)$ for different periods before a $\left.{ }^{3} \mathrm{H}\right]$ thymidine pulse of 1 h duration. Between 14 and 22 cells per point were evaluated. Bar, S.D.M.

cells autoradiographic label was found concentrated at one place in the nucleus (fig. $1 b$, table 1). In unirradiated controls this pattern was not observed. Evidence that the label was actually induced at the irradiation site was obtained by video tape recordings of the irradiation experiment [15]. A quantitative evaluation of grain densities in non $S$ phase cells showed that $\left[{ }^{3} \mathrm{H}\right]$ thymidine incorporation is restricted to the irradiation site and adjacent nuclear areas (fig. 2). In nuclear regions remote $(>6 \mu \mathrm{m})$ from the irradiation site no UDS could be detected (fig. 2) [4]. The amount of UDS depended on the UV energy delivered (fig. 2) and its rate decreased to approx. $50 \%$ of the initial rate within the first $4 \mathrm{~h}$ after microirradiation (fig. 3).

\section{Detection of label after a chase and a growth period}

In other experiments cells were grown for $42 \mathrm{~h}$ after a chase period and chromosome preparations were performed. Label indicating UDS was still clearly concentrated to 
Table 1. Frequency of autoradiographic patterns observed after $U V$ microirradiation of cell nuclei and incubation with $\left[{ }^{3} \mathrm{H}\right] \mathrm{Td} R$

\begin{tabular}{|c|c|c|c|c|c|c|c|}
\hline \multicolumn{2}{|c|}{$\begin{array}{l}\text { Cell no. at time of } \\
\text { irradiation }\end{array}$} & \multirow[b]{2}{*}{ Treatment } & \multirow[b]{2}{*}{$\begin{array}{l}\text { Cell no. } \\
\text { evaluated }\end{array}$} & \multicolumn{4}{|c|}{ Label type } \\
\hline $\begin{array}{l}\text { Ir- } \\
\text { radiated }\end{array}$ & $\begin{array}{l}\text { Not } \\
\text { irradiated }\end{array}$ & & & S phase & $\begin{array}{l}\text { No } \\
\text { label }\end{array}$ & $\begin{array}{l}\text { Local- } \\
\text { ized }\end{array}$ & $\begin{array}{l}\text { Un- } \\
\text { clear }\end{array}$ \\
\hline 113 & $\begin{array}{l}0 \\
\text { n.d. }\end{array}$ & $\begin{array}{l}\text { Schedule } A^{a} \\
\text { Interphase nuclei } \\
\text { Experimental cells } \\
\text { Controls }\end{array}$ & $\begin{array}{r}86 \\
166\end{array}$ & $\begin{array}{l}16 \\
18\end{array}$ & $\begin{array}{r}5 \\
148\end{array}$ & $\begin{array}{r}64 \\
0\end{array}$ & $\begin{array}{l}1 \\
0\end{array}$ \\
\hline \multirow[t]{2}{*}{5809} & 272 & $\begin{array}{l}\text { Schedule } B^{a} \\
\text { Experimental cells } \\
\text { Interphase nuclei } \\
\text { Metaphase plates }\end{array}$ & $\begin{array}{l}939^{\circ} \\
119\end{array}$ & $\begin{array}{r}169 \\
3\end{array}$ & $\begin{array}{r}162 \\
79\end{array}$ & $\begin{array}{r}596 \\
28\end{array}$ & $\begin{array}{r}12 \\
9\end{array}$ \\
\hline & n.d. ${ }^{b}$ & $\begin{array}{l}\text { Controls } \\
\text { Interphase nuclei } \\
\text { Metaphase plates }\end{array}$ & $\begin{array}{l}904 \\
108\end{array}$ & $\begin{array}{r}134 \\
9\end{array}$ & $\begin{array}{r}767 \\
98\end{array}$ & $\begin{array}{l}1 \\
0\end{array}$ & $\begin{array}{l}3 \\
1\end{array}$ \\
\hline
\end{tabular}

one part of the nucleus in most of the microirradiated cells (fig. $1 c$, table 1 ). In experimental and in control fields some cells had been in $\mathrm{S}$ phase during the label period as indicated by heavy labelling distributed over the whole nucleus. Very few control cells which were presumably labelled at the onset or at the end of $S$ phase resulted in grain counts between 50 and 200 (fig. $4 b$ ). The grain counts in experimental "non $S$ phase" nuclei showed a broad distribution and were clearly increased above the low grain counts found in most control cells (fig. $4 a, b$ ). The grain density in "non $\mathrm{S}$ phase" control nuclei was increased over the levels found in the cytoplasm or in areas free from cells (data not shown), but was independent of whether schedule A or schedule B was applied. Presently we do not know whether this finding is due to technical shortcomings or indicates a very low amount of DNA repair in unirradiated cells.

\section{Detection of label on metaphase chromosomes}

In 28 of the metaphase plates found within experimental fields after treatment following schedule B, label patterns were observed which clearly differed from those of metaphase plates in control fields, in grain number as well as in the spatial distribution of the grains: Grain counts in these metaphase plates were increased and fell in the range characteristic for nuclei of irradiated cells (fig. 4a), Typically most of the irradiation-induced grains were found concentrated on a few chromosomes which lay adjacent to each other in one region of the metaphase plate (fig. 5). This was also often found in metaphase plates (figs $5 c, f$ ) in which the labelled chromosomes were not connected by rearrangements (see figs $5 a$, $b, d, e)$ or damaged and by this possibly sticky. Chromosomes outside the labelled region showed grain densities as found in control metaphase plates. A concentration 


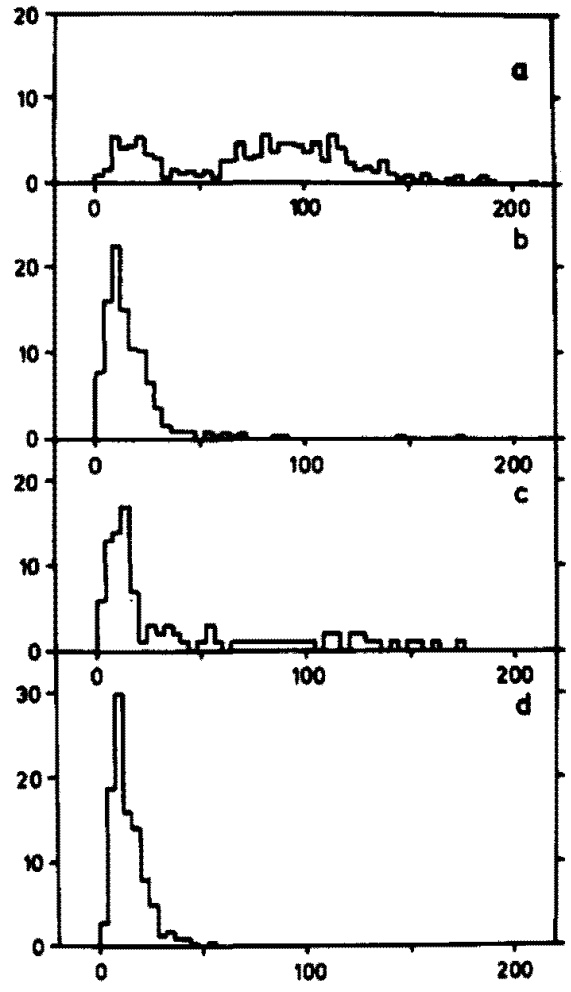

Fig. 4. Abscissa: grain no./cell; ordinate: $\%$ of cells. Histograms of grain number found in autoradiographs on chromatin of microirradiated and control cells treated following schedule B: $(a, b)$ Interphase nuclei: $(a)$ experimental cells $(n=401) ;(b)$ controls $(n=360) ;(c, d)$ metaphase plates: $(c)$ experimental cells $(n=98) ;(d)$ controls $(n=223)$. Cells with grain counts above 200 showed $S$ phase incorporation distributed over the whole nucleus. These cells were not included into the histograms.

of grains at one site could also be found in some metaphase plates in which the total grain number was in the range observed on control metaphase plates (fig. $5 f$ ).

In cases where the analysis of the karyogram was possible, label patterns were observed (fig. $5 g$ ) which were not found in mitotic figures of controls and were different from the pattern of normal DNA replication in Chinese hamster cells as investigated by autoradiography $[16,17]$ and differential staining $[17,18, W$. Schempp, pers. commun.]. At the end of S phase incorporation into only a restricted number of chromosomal region is also observed, but in this case, besides some heterochromatic autosomal regions, the $\mathrm{X}$-chromosomes are heavily labelled and the labelled chromosomes are not concentrated in one part of the metaphase plate $[16,17]$. A similar time-course of replication is found in homologous autosomes $[16,17]$. In the present experiments label was found on few autosomes while the $\mathrm{X}$-chromosomes and in most cases the corresponding homologues were unlabelled and lay more or less remote from the labelled part of the metaphase plate. In one cell (fig. $5 g$, karyotype no. II) out of the four largest chromosomes one chromosome no. 1 was unlabelled and intact, while the other three chromosomes including both chromosomes no. 2 were affected by irradiation-induced alterations.

The present experiments are summarized in table 1 which confirms that induction of local label in metaphase plates is an effect of irradiation. Besides locally labelled metaphase plates other metaphase plates are found within the experimental fields which display a label pattern comparable to that of control metaphase plates: either low grain counts distributed over the whole metaphase plate, or $S$ phase label on all chromosomes or on the late replicating regions [ 16 , 17]. "Non labelled" metaphase plates in experimental fields are presumed to originate from unirradiated cells which have been excluded from or were overlooked during irradiation. On the other hand label in some irradiated cells may have escaped detection due to low grain counts, which could be expected on the basis of the considerable variation of the UDS response (fig. 4a). Furthermore it seems possible that cells with a high UDS response had a selective disadvantage due to harmful effects of $\left[{ }^{3} \mathrm{H}\right]$ - 
Zorn et al.

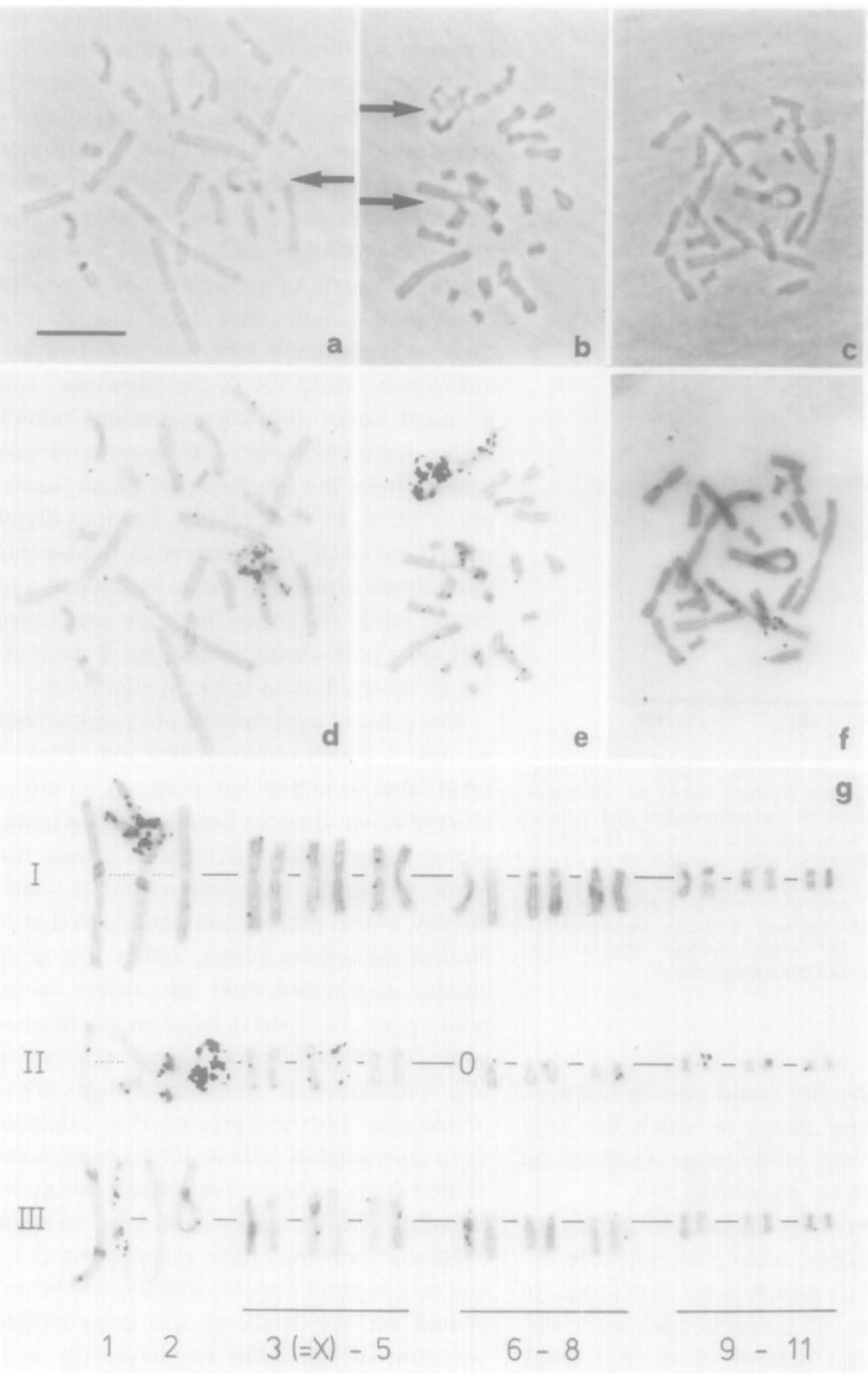


thymidine decay compared with cells with a low UDS response (compare fig. $4 a, c$ ). The "unclear" label pattern observed in very few control cells (table 1) might result from incorporation into late replicating chromatin or from a random accumulation of some grains at one site.

We frequently observed that unscheduled label was associated with chromosome damage or miscondensation (fig. $5 a, b$ ). We suppose that the action of UV light and decay of tritium which was incorporated in the course of UDS is the cause of this effect. Chromosome damage was possibly also induced by the action of tritium decay alone as suggested by the finding that in $S$ phase-labelled control cells the frequency of micronuclei was increased compared with non-labelled cells ( $11 \%$ vs $1.2 \%$ ).

\section{DISCUSSION}

It is widely accepted that unscheduled DNA synthesis (UDS) can be interpreted as incorporation of $\left[{ }^{3} \mathrm{H}\right]$ thymidine into DNA in the course of the excision repair process [2]. The existing data $[5-7,9]$ suggest that the same interpretation can be applied to localized label found after partial microirradiation of nuclei of mammalian cells in cell culture with ultraviolet light: UVinduced label is observed after microirradiation of the nucleus (fig. $1 b$ ) $[4-7,15]$ but not of the cytoplasm [5, 7]. The number of induced grains follows a dose-effect relationship (fig. 2) [6, 7]. The pattern of label re-

Fig. 5. Chromosome preparations of cells microirradiated in the nucleus and treated following schedule B. $(a-c)$ Phase contrast micrographs made before autoradiography; $(d-f)$ autoradiographs and $(g)$ karyograms of the metaphase plates shown in $(a)-(c)$, respectively. Arrows indicate chromosome damage, 0 indicates a missing chromosome. The remnants of this are presumably contained in the damaged chromosomes. Bar, $10 \mu \mathrm{m}$. flects the spatial distribution of UV light in nuclei at the time of irradiation (fig. 2) [6, 7]. Silver grains were induced over the whole nuclear area in cases where the whole nucleus had been exposed to irradiation instead of a small part (unpublished results). These results show that label incorporation is an effect of the irradiation of nuclear material. The radioactivity cannot be removed by extensive washing with cold PCA or TCA but was shown by Moreno to be sensitive to treatment of the fixed cells with DNase [5]. This indicates incorporation into DNA. Moreno showed that localized label could not be induced in excision repair deficient Xeroderma pigmentosum cells [6]. Since in the present experiments the timecourse of the amount of localized label (fig. 3 ) is similar to that reported by other authors for UDS and repair replication [19, 20 ], we assume that local label was induced as a result of excision repair in the microirradiated part of the nucleus.

In this report we have presented evidence that chromatin contained in a small part of the nucleus can be selectively labelled by UDS after laser UV microirradiation and that the label can be relocated in metaphase preparations. Our conclusion is based on a comparison of the grain numbers found over microirradiated nuclei with the grain numbers found over metaphase plates in experimental fields (fig. 4), as well as on the distribution of label in 28 metaphase plates. Such a localized type of distribution (fig. 5) was not observed in control fields (table 1) and this type clearly differs from the distribution of label expected as a consequence of pulse labelling during $S$ phase.

Under suitable conditions, especially after microirradiation of the nucleus in $\mathrm{S}$ phase ([4], unpublished data), shattering restricted to few chromosomes can be found when cells have been post-treated with caf- 
feine. We have followed this approach using chromosome damage as a "label" for microirradiated chromatin [10]. As in the present experiments using UDS label the damaged chromosomes were closely associated in one part of the metaphase plate, and homologous chromosomes were not necessarily jointly affected. The possibility of identifying microirradiated chromatin on chromosomes of the subsequent metaphase provides a novel access to information on the spatial arrangement of the chromosomes during interphase. The two label methods are complementary in that the UDS label method can only be used in G1 or G2 phase while partial shattering is preferably induced in $\mathrm{S}$ phase. The results of the present experiments support the hypotheses which were developed on the basis of our previous data [10]:

The decondensed interphase chromosomes seem to occupy rather compact "territories" [21-23] and are not extruded throughout the nucleus (for models see [24, 25]). This is indicated by the fact that often only a few chromosomes within one cell are labelled.

The expectation from the experimental protocol that UDS-labelled mitotic cells had been irradiated during Gl is supported by results from recent experiments (C. Cremer, to be published elsewhere) which indicated that mitotic cells with local label originated from cells microirradiated before the onset of the last $S$ phase before preparation. The concentration of UDS label at one site in metaphase plates and interphase nuclei observed after microirradiation in the G1 phase taken together with a concentration of chromosome damage at one part of the metaphase plate after irradiation in $S$ phase and caffeine posttreatment ([10] and unpublished data) suggest that the microirradiated chromosome segments had not separated from each other during the post-irradiation incubation. This supports the view that in mammalian cells there are no drastic changes in the relative chromosome positions during the course of the cell cycle $[26,27]$ as has been suggested for other cell systems [28, 29]. At the UV energies applied in these experiments, however, the possibility of an inhibition of the movement of microirradiated chromatin [7] e.g. by the induction of chromosome rearrangements as shown in fig. $5 a, b$, should be kept in mind. Detailed studies on the temporal changes of the distribution of microirradiation-induced UDS within nuclei of growing cells, using different UV energies, are in progress.

With the microirradiation approach, a joint labelling of chromosomal regions would indicate that these regions had been situated adjacent to each other within the irradiation field at the time of irradiation. It has been proposed that an association of homologous chromosomes as observed in diptera $[21,30]$ and some plant species $[23$, $32-34]$ occurs also in mammalian cells ([24, 26, 35-38]; for contrary findings see e.g. $[36,37,39,40])$. In our experiments karyograms analyzed so far (e.g. in fig. $5 \mathrm{~g}$ ) demonstrate homologous chromosomes which are not jointly labelled. This result does not support the assumption of a very close and permanent association of all chromosomes with their respective homologues over the whole chromosome length. However, an association occurring only at a certain stage during the cell cycle or in specific chromosome regions [24] is still possible. It may be noted that in one metaphase plate both chromosomes no. 2 were involved.

With respect to a further analysis of possible random or non-random arrangements of homologous and non-homologous chromosomes during interphase $[24,26,41]$ our 
approach may be limited (1) by the small numbers of metaphase plates with UDS label obtained from a large number of microirradiated G1 cells. It is hoped that the approach can be considerably improved in this respect. (2) The possibility has to be considered that the picture of the relative involvement of different chromosomal regions may be distorted by a different UDS response of different chromosomes or parts of chromosomes [42-45]. (3) Each metaphase figure with UDS label represents a clear picture of the distribution of the chromosomes at the irradiated part of the interphase nucleus. However, the possibility of selective pressure against cells containing photolesions in specific gene loci or gene combinations should be kept in mind, when an analysis of random and non-random chromosome associations is attempted by this method.

This work was supported by grants of the Deutsche Forschungsgemeinschaft (Az. Wo 148/16 and SFB 46). We thank Professor T. M. Schroeder and Professor U. Wolf for stimulating discussions.

\section{REFERENCES}

1. Rasmussen, R E \& Painter, R B, Nature 203 (1964) 1360.

2. Cleaver, J E, Advan radiat biol 4 (1974) 1.

3. Zorn, C, Cremer, C, Cremer, T\& Zimmer, J, Proc symp Lasers in medicine and biology, p. 30/1. Ges. Strahlen- und Umweltforsch., Munich (1977).

4. Cremer, T, Cremer, C, Zimmer, J \& Zorn, C, DNA repair and late effects (ed $\mathrm{H}$ Altmann \& $\mathrm{H}$ Schor). In press.

5. Moreno, G, Exp cell res 65 (1971) 129.

6. Moreno, G \& Salet, C, Radiat res 58 (1974) $\$ 2$.

7. Yatani, R, Mie med j 20 (1970) 93.

8. Sakharov, V N, Voronkova, L N, Pyruzyan, L A \& Lomakina, L Y, Nature 260 (1976) 784.

9. - Tsytologija 18 (1976) 1111 .

10. Zorn, C, Cremer, T, Cremer, C \& Zimmer, J, Hum genet 35 (1976) 83.

11. Cremer, C, Zorn, C \& Cremer, T, Microsc acta 75 (1974) 331 .

12. Cremer, C, Cremer, T, Zorn, C \& Schoeller, L, Radiat res 66 (1976) 106.

13. Cremer, C, Thesis, University Freiburg i. Br. (1976).

14. Cremer, C, Zorn, C, Cremer, T \& Cioreanu, V, Arch genet 51 (1978) 2 .
15. Zorn, C, Thesis, University Freibrug i.Br. (1978).

16. Hsu, T C, J cell biol 23 (1964) 53.

17. Deaven, L L \& Petersen, D F, Chromosoma (Berl.) 41 (1973) 129.

18. Schempp, W \& Vogel, W, Chromosoma 73 (1979) 109.

19. Ehmann, U K, Cook, K H \& Friedberg, E C, Biophys j 22 (1978) 249.

20. Williams, J I \& Cleaver, J E, Biophys j 22 (1978) 265.

21. Brown, S \& Nur, U, Science 145 (1964) 130.

22. Robards, A W, Electron microscopy and plant ultrastructure. McGraw-Hill, Maidenhead (1970).

23. Werry, P A T J, Stoffelsen, K, Engels, F M, van der Laan, F \& Spanjers, A W, Chromosoma (Berl.) 62 (1977) 93 .

24. Vogel, F \& Schroeder, T M. Humangenetik 25 (1974) 265 .

25. Ghosh, S \& Roy, S C, Chromosoma (Berl.) 61 (1977) 49 .

26. Comings, D E, Am j hum genet 20 (1968) 440 .

27. Schwarzacher, $\mathrm{H} \mathrm{G}$, Chromosomes in mitosis and interphase. Springer, Berlin, Heidelberg and New York (1976).

28. Loza Bonifaz, E \& Plaut, W, Chromosoma (Berl.) 46 (1974) 261

29. Hobarth, P, Duncan, $R$ \& Infante, A A, Nature 267 (1977) 542 .

30. Nichols, W W, Bradt, C, Dwight, S \& Bowne, W, Cytogenet 11 (1972) 46.

31. Diaz, G \& Lewis, K R, Chromosoma (Berl.) 52 (1975) 27

32. Feldman, M \& Avivi, L, Proc 4th internat wheat genet symp, p. 675. Columbia, Mo (1973).

33. Godin, D E \& Stack, S M, Chromosoma (Berl.) 57 (1976) 309.

34. Singh, R J, Röbbelen, G \& Okamoto, M, Chromosoma (Berl.) 56 (1976) 265.

35. Heneen, $W \mathrm{~K} \&$ Nichols, $W \mathrm{~W}$, Cytogenet 11 (1972) 153.

36. Juricek, D K, Chromosoma (Berl.) 50 (1975) 313.

37. Hens, L, Kirsch-Volders, M, Susanne, C \& Galperin-Lemaitre, H, Humangenetik 28 (1975) 303.

38. Dutrillaux, B, Aurias, A, Couturier, J, Croquette, M F \& Viegas -Pequignot, E, Chromosomes today (ed A de la Chapelle \& M Sorsa) vol. 6, p. 37. Amsterdam (1977).

39. Cohen, M M, Enis, P \& Pfeifer, C G, Cytogenet 11 (1972) 145

40. Warburton, D, Naylor, A F \& Warburton, F E, Humangenetik 18 (1973) 297.

41. Bostock, C J \& Sumner, A T, The eucaryotic chromosome, p. 196. North-Holland, Amsterdam (1978).

42. Berliner, J, Santos Mello, R \& Norman, A, Radiat res 68 (1976) 509.

43. Harris, C C, Connor, R J, Jackson, F E \& Lieberman, M W, Cancer res 34 (1974) 3461.

44. Johnson, $R$ T \& Sperling, $K$, Int $\mathrm{j}$ radiat biol 34 (1978) 575

45. Wilkins, R J \& Hart, R W, Nature 247 (1974) 35.

Received March 22, 1979

Revised version received May 29, 1979

Accepted June 6, 1979 